Research Paper

\title{
Pharmacological inhibition of lipid droplet formation enhances the effectiveness of curcumin in glioblastoma
}

\author{
Issan Zhang ${ }^{\mathrm{a}, 1}$, Yiming Cui ${ }^{\mathrm{a}, 1}$, Abdolali Amiri ${ }^{\mathrm{a}}$, Yidan Ding ${ }^{\mathrm{b}}$, Robert E. Campbell ${ }^{\mathrm{b}}$, Dusica Maysinger ${ }^{\mathrm{a}, *}$ \\ ${ }^{a}$ Department of Pharmacology and Therapeutics, McGill University, Montreal, Canada \\ ${ }^{\mathrm{b}}$ Department of Chemistry, University of Alberta, Edmonton, Canada
}

\section{A R T I C L E I N F O}

\section{Article history:}

Received 16 September 2015

Revised 14 December 2015

Accepted in revised form 18 December 2015

Available online 4 January 2016

\section{Keywords:}

Glioblastoma

Lipid droplets

Curcumin

Pyrrolidine-2

Caspase-3 sensor

Cell death

Sensitization

Temozolomide

Spheroids

Chemotherapy

\begin{abstract}
A B S T R A C T
Increased lipid droplet number and fatty acid synthesis allow glioblastoma multiforme, the most common and aggressive type of brain cancer, to withstand accelerated metabolic rates and resist therapeutic treatments. Lipid droplets are postulated to sequester hydrophobic therapeutic agents, thereby reducing drug effectiveness. We hypothesized that the inhibition of lipid droplet accumulation in glioblastoma cells using pyrrolidine-2, a cytoplasmic phospholipase A2 alpha inhibitor, can sensitize cancer cells to the killing effect of curcumin, a promising anticancer agent isolated from the turmeric spice. We observed that curcumin localized in the lipid droplets of human U251N glioblastoma cells. Reduction of lipid droplet number using pyrrolidine-2 drastically enhanced the therapeutic effect of curcumin in both $2 \mathrm{D}$ and 3D glioblastoma cell models. The mode of cell death involved was found to be mediated by caspase-3. Comparatively, the current clinical chemotherapeutic standard, temozolomide, was significantly less effective in inducing glioblastoma cell death. Together, our results suggest that the inhibition of lipid droplet accumulation is an effective way to enhance the chemotherapeutic effect of curcumin against glioblastoma multiforme.
\end{abstract}

(C) 2016 Published by Elsevier B.V.

\section{Introduction}

In cancers such as glioblastoma multiforme, enhanced fatty acid storage and synthesis provide the necessary resources for survival and rapid proliferation [1]. Although otherwise highly heterogeneous, most cancer types present a lipogenic phenotype characterized by the upregulation of key enzymes and transcriptional factors controlling lipid metabolism (e.g. Akt, fatty acid synthase, hypoxia-inducible factor 1-alpha, sterol regulatory element binding proteins, acetyl-CoA carboxylase alpha), and a boost in de novo lipogenesis [2-5]. In solid malignancies, the hypoxic conditions found at the core of the tumors induce adaptive pathways aimed at maintaining lipid synthesis, homeostatic $\mathrm{pH}$ and cell survival [6]. The resulting metabolic changes correlate with poor prognosis, poor treatment response and recurrence in diseases such as breast, liver and brain cancer [7-10]. Emerging therapeutic approaches have thus targeted lipid synthesis to counter the effects of metabolic reprogramming in cancer cells [11,12].

\footnotetext{
* Corresponding author.

E-mail address: dusica.maysinger@mcgill.ca (D. Maysinger).

1 These authors contributed equally to this work.
}

Aside from their increased de novo fatty acid synthesis, cancer cells are also characterized by their increased number of lipid droplets compared to normal tissues [13,14]. Lipid droplets are dynamic organelles that support cells with metabolic fuel, membrane biosynthesis, inflammatory intermediates and signaling mediators [15-17]. Although they can be found in almost all cell types, their increased biogenesis in neoplastic and inflammatory conditions defines them as targets for therapeutic intervention [18]. Aside from fueling the accelerated metabolism of cancer cells, lipid droplets also harbor numerous proteins and transcription factors critical to lipid metabolism and related pathways [19]. The hydrophobic core found in lipid droplets provides a favorable compartment to attract and sequester lipophilic proteins and compounds, fat-soluble vitamins, and even environmental pollutants [20]. As such, lipid droplets can sequester lipophilic drugs and prevent them from reaching their targets, thus decreasing drug effectiveness [21,22]. Therefore, it seems that inhibition by pharmacological or genetic means of enzymes necessary for lipid droplet formation could provide a way to reduce drug sequestration and improve drug effects. We tested this concept in glioblastoma cells treated with curcumin in combination with pyrrolidine-2, and inhibitor of cytosolic phospholipase A2 alpha $(\mathrm{CPLA} 2 \alpha)$. Curcumin, a plant-derived polyphenol isolated from 
the turmeric spice, has been shown to be a safe, potent and effective anticancer agent both in vitro and in vivo [23]. It was found to affect multiple targets, leading to the inhibition of inflammation and cell proliferation [24]. Curcumin has a broad range of effects that are advantageous against multifactorial diseases such as cancer, and clinical trials have suggested biological activity in patients with colorectal and pancreatic cancer [25,26]. Despite being welltolerated in humans, its poor bioavailability has limited prospects of broader clinical applications [26,27]. Given its lipophilic properties, curcumin has been found to localize in lipid membranes and lipid droplets, thereby decreasing its availability at drug targets. Pyrrolidine-2, also known as pyrrophenone, is a potent and reversible inhibitor of cPLA $2 \alpha$, a key enzyme in the processes of arachidonic acid release, eicosanoid synthesis and lipid droplet formation $[28,29]$. We hypothesize that pre-treatment of cancer cells with pyrrolidine- 2 will enhance the cell killing effect of curcumin by reducing its sequestration in lipid droplets.

Glioblastoma multiforme is a highly aggressive and drugresistant type of brain cancer which currently lacks effective treatments [30,31]. Temozolomide, a DNA methylating agent, is the first-line drug used in concomitant and adjuvant radiochemotherapy against glioblastoma [32-34]. However, a large subset of patients is resistant to temozolomide due to the expression of the $\mathrm{O}^{6}$-methylguanine-DNA methyltransferase gene (MGMT), a DNA repair protein, and there is an urgent need for alternative mono- and combination therapies [35]. We have investigated the susceptibility of human glioblastoma monolayer (2D) and spheroid (3D) cultures to curcumin and temozolomide used either individually or in combination with pyrrolidine-2. We also compared the effect of pyrrolidine-2 to that of buthionine sulfoximine (BSO), an irreversible inhibitor of gamma-glutamylcysteine synthetase, the rate-limiting enzyme in glutathione synthesis, found to be effective as a sensitizing agent in patient-derived neuroblastoma cell lines [36,37].

We further monitored the mode of cell death induced by these treatments using a newly developed, dimerization-based biosensor which provides a highly sensitive method to visualize and quantify caspase-dependent apoptotic activity in living cells [38]. The cysteine protease caspase- 3 is a main executioner caspase in the process of caspase-dependent apoptosis $[39,40]$. It was shown to be strongly activated in response to curcumin treatment in different cell lines [41-43]. By investigating the activity of caspase-3 in cancer cells in response to chemotherapeutics and sensitizers, we can reveal drug efficacy and underlying mechanisms of cell death.

The objective of these studies was to investigate the sensitization of human glioblastoma cells in 2D and 3D cultures to caspase-3-mediated cell death induced by curcumin. We used the pharmacological agent pyrrolidine- 2 to manipulate lipid droplet number in glioblastoma cells and assessed caspase- 3 activity in living cells using a recently developed biosensor. The results indicate a significant increase in caspase-3-mediated cell death induced by curcumin when lipid droplet formation is reduced.

\section{Materials and methods}

\subsection{Materials}

Curcumin (Sigma-Aldrich, Canada), pyrrolidine-2 (Calbiochem, United States), temozolomide (Sigma-Aldrich, Canada), buthionine sulfoximine (Sigma-Aldrich, Canada), staurosporine (SigmaAldrich, Canada), dimethyl sulfoxide (Sigma-Aldrich, Canada), Nile Red (Sigma-Aldrich, Canada), paraformaldehyde (Sigma-Aldrich, Canada), BODIPY 493/503 (Invitrogen, Canada), Hoechst 33342 (Sigma-Aldrich, Canada) and propidium iodide (Sigma-Aldrich, Canada) were used as received.
Table 1

Construct of Plasmid 1 and Plasmid 2, which form the caspase-3 biosensor.

\begin{tabular}{|c|c|c|c|}
\hline Name & Gene & $\begin{array}{l}\text { GenBank } \\
\text { accession } \\
\text { numbers }\end{array}$ & $\begin{array}{l}\text { Addgene } \\
\text { plasmid ID }\end{array}$ \\
\hline $\mathrm{GA}^{\mathrm{NES}}-\mathrm{DEVD}-\mathrm{B}^{\mathrm{NLS}}$ & $\begin{array}{l}\text { Xhol-GA-NES-KpnI- } \\
\text { DEVD-B-NLS-HindIII }\end{array}$ & KF976777 & 50842 \\
\hline $\mathrm{RA}^{\mathrm{NLS}}$ & Xhol- RA-NLS-HindIII & KF976778 & 50843 \\
\hline
\end{tabular}

\subsection{Cell culture}

The U251N human glioblastoma cell line was originally obtained from the American Type Culture Collection. Unless otherwise specified, U251N cells were cultured in Dulbecco's Modified Eagle's Medium (DMEM; Invitrogen, Canada) containing 10\% (v/v) fetal bovine serum (Invitrogen, Canada), $2 \mathrm{mM} \mathrm{L}$-glutamine, $100 \mathrm{IU} / \mathrm{mL}$ penicillin, $100 \mu \mathrm{g} / \mathrm{mL}$ streptomycin (Invitrogen, Canada), and $1 \%$ non-essential amino acids. Cells were incubated at $37{ }^{\circ} \mathrm{C}$ with $5 \% \mathrm{CO}_{2}$.

\subsection{Spheroid preparation}

Spheroid cultures were prepared using a protocol adapted from the previously established liquid overlay system: confluent U251N monolayer cell cultures were detached using 0.05\% trypsin-EDTA (Invitrogen, Canada), and seeded at 5,000 cells per well in 96well plates pre-coated with $2 \%$ agarose (Invitrogen, Canada) in serum-deprived DMEM [44]. Spheroids were seeded and maintained in complete DMEM medium for four days before drug treatments. Spheroids expressing the caspase-3 biosensor were prepared following the same method, using transfected cells.

\subsection{Cell treatment}

Confluent monolayer cell cultures were detached using $0.05 \%$ trypsin-EDTA, seeded in 24-well or 96-well cell culture plates (Sarstedt, Canada) at 50,000 or 10,000 cells per well, respectively, and treated after $24 \mathrm{~h}$. For $24 \mathrm{~h}$ dose-response experiments, drugs were administered in the following concentrations: curcumin (Cur; 5-100 $\mu \mathrm{M}$ ); pyrrolidine-2 (Pyr-2; 1-5 $\mu \mathrm{M}$ ). For 72 h dose-response experiments, curcumin was added at concentrations 5-30 $\mu \mathrm{M}$. For pyrrolidine- $2(3 \mu \mathrm{M})$ and buthionine sulfoximine (BSO; $5 \mathrm{mM}$ ) pretreatments, cells were treated for $24 \mathrm{~h}$, after which the medium was refreshed. To establish the time course of drug effects in spheroid cultures, treatments were maintained for $24 \mathrm{~h}$ or $72 \mathrm{~h}$. BSO stocks $(200 \mathrm{mM})$ were prepared fresh in purified water. Stock solutions of temozolomide, curcumin, staurosporine and pyrrolidine-2 were prepared in dimethyl sulfoxide (DMSO), and added to cells for a final DMSO concentration $<0.5 \%$. Vehicle controls were included in each experiment.

\subsection{Lipid droplet labeling, imaging and quantification}

After treatment with curcumin $(10-30 \mu \mathrm{M})$ for $24 \mathrm{~h}$, the media were refreshed, and cells were incubated with Nile Red $(2 \mu \mathrm{M}$; $10 \mathrm{~min}$ ). Nile red is a commonly used fluorescent label for lipid droplets $[45,46]$, but it can also bind to hydrophobic protein domains and be employed to probe hydrophobic pockets in purified native proteins [47]. Labeled cells were washed with phosphate buffered saline (PBS), and imaged using a fluorescence microscope (Leica, Canada). To quantify the number of lipid droplets per cell, U251N cells were fixed with paraformaldehyde (4\%; $15 \mathrm{~min}$ ) following treatment, labeled with BODIPY 493/503 ( $2 \mu \mathrm{M} ; 10 \mathrm{~min}$ ), and then imaged using a fluorescence microscope. 
A

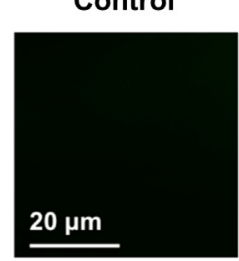

B

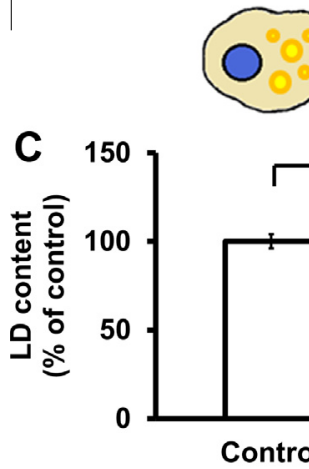

Curcumin

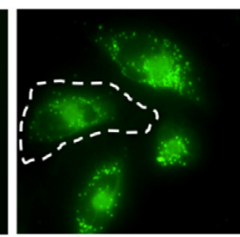

Curcumin

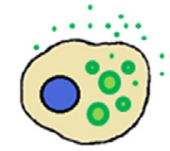

Nile Red

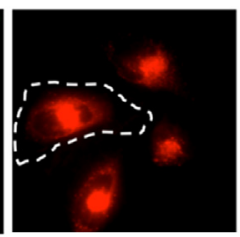

Pyrrolidine-2
Overlay

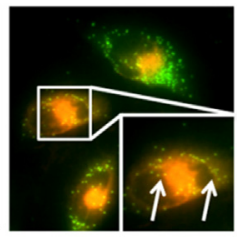

Curcumin +

Pyrrolidine-2

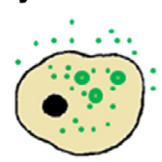

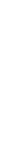

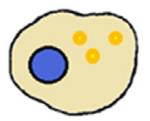

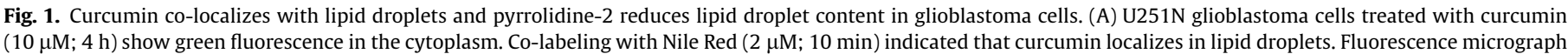

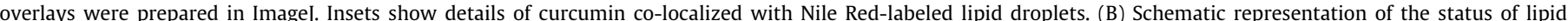

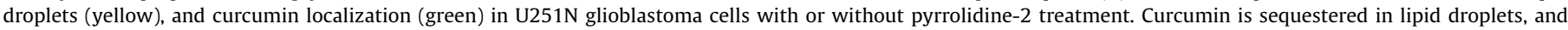

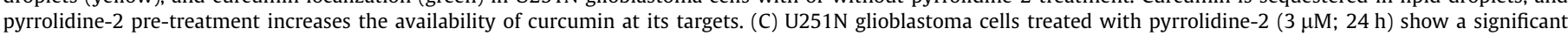

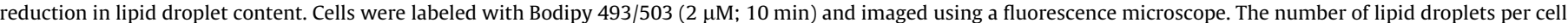

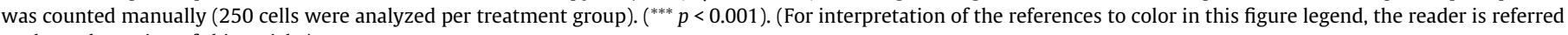
to the web version of this article.)

A

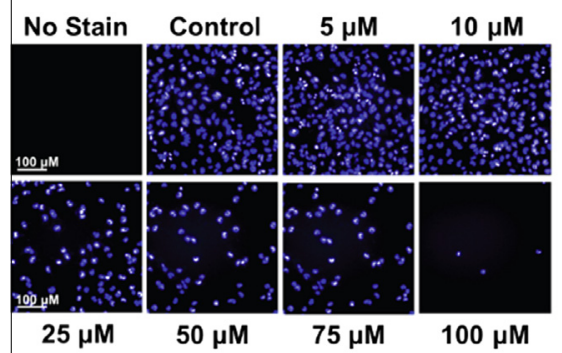

C

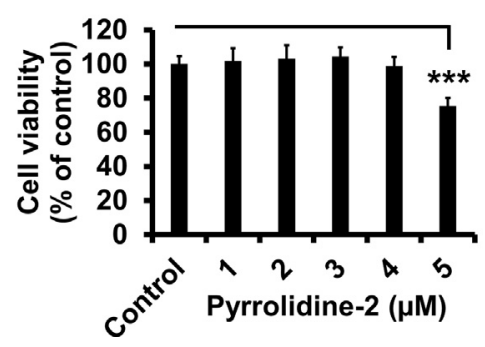

B

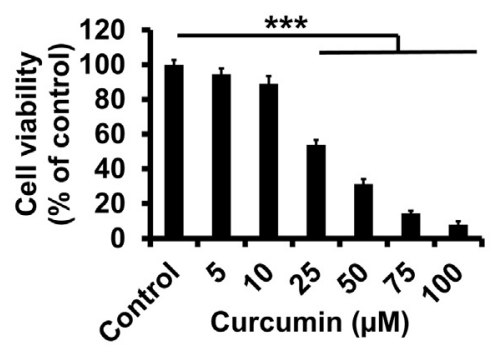

D

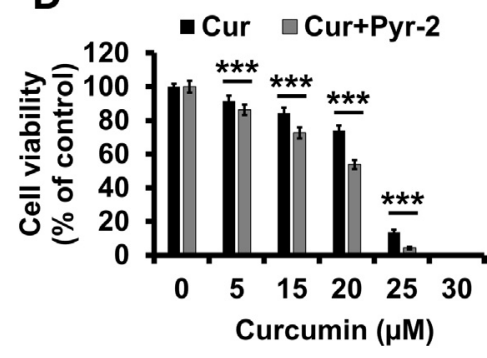

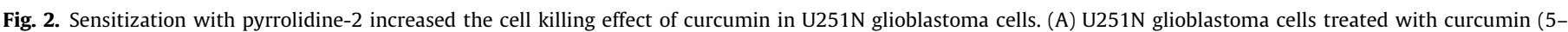

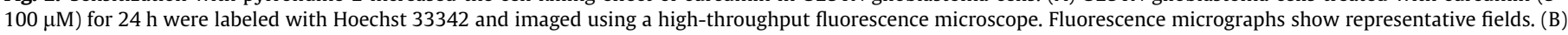

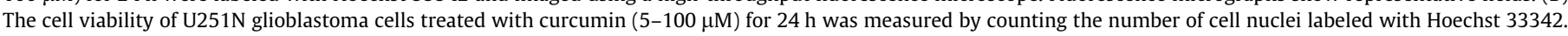

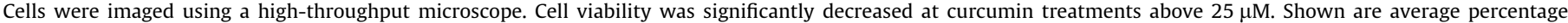

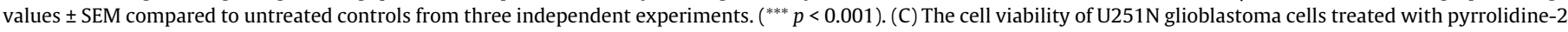

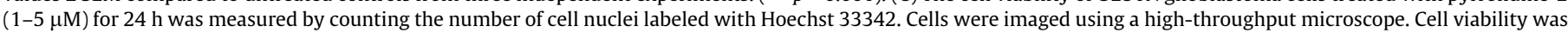

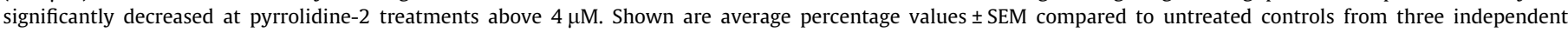

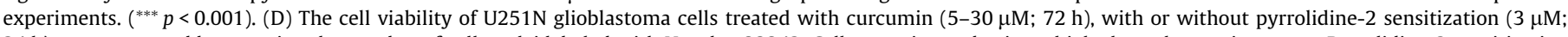

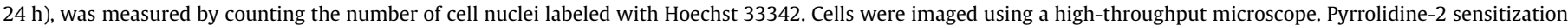

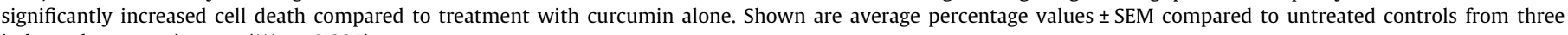
independent experiments. $\left({ }^{* * *} p<0.001\right)$. 

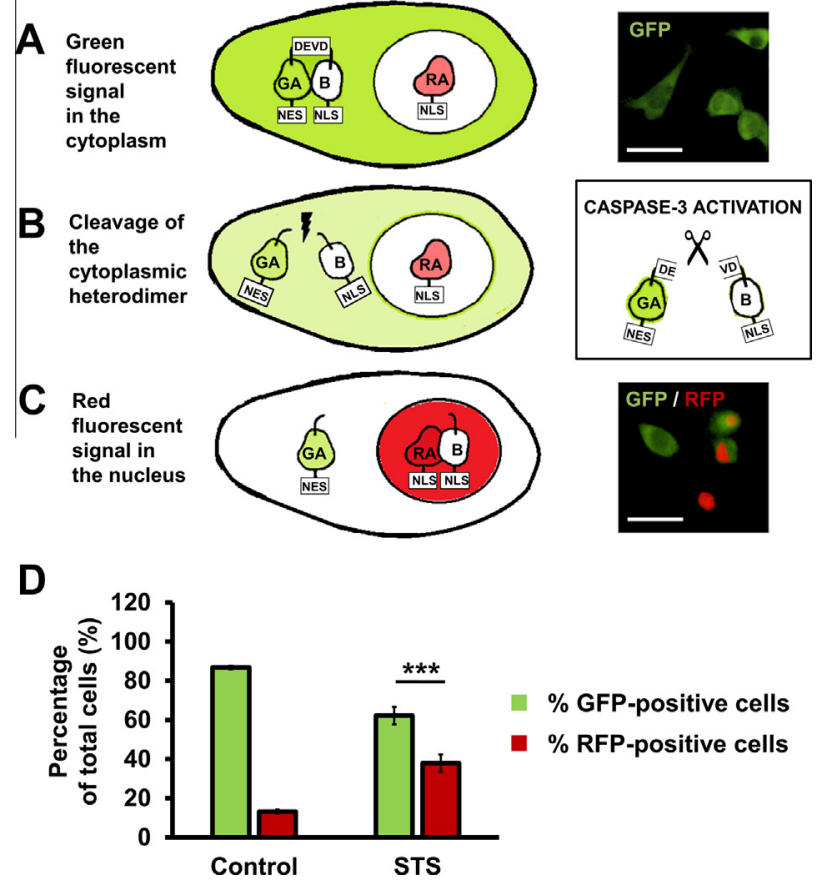

Fig. 3. Principle of caspase- 3 detection using the dimerization-based biosensor and measurement of caspase- 3 activity. (A) The caspase- 3 biosensor is composed of two dimerization-dependent fluorescent proteins: (1) a red fluorescent protein (RA) with a nuclear localization signal (NLS), and (2) a green fluorescent protein (GA) with a nuclear exclusion signal (NES), heterodimerized with a non-fluorescent partner protein (B) through the caspase-3 substrate peptide (DEVD). Fluorescence micrographs show U251N cells with green cytoplasms when GA is heterodimerized with B (scale bar $=50 \mu \mathrm{m}$ ). (B) Upon caspase-3 activation, the caspase- 3 substrate DEVD is cleaved, and green fluorescence signal from GA diminishes. (C) The partner protein $B$ translocates into the nucleus by a NLS and heterodimerizes with RA, increasing red fluorescence in the nucleus manyfold. Fluorescence micrographs show U251N cells with red nuclei when RA is heterodimerized (scale bar $=50 \mu \mathrm{m}$ ) (D) Measurement of caspase-3 activity in U251N glioblastoma cells. Cells transfected with the biosensor were imaged using a fluorescence microscope following treatment with staurosporine (STS; $0.5 \mu \mathrm{M}$ ) for $24 \mathrm{~h}$. Cells with active caspase-3 show an increase in red fluorescence (RFP) in the nucleus and a decrease in green fluorescence (GFP) in the cytoplasm. Mean percentage of total transfected cells expressing GFP or $\mathrm{RFP} \pm \mathrm{SEM}$ is shown for three independent experiments ${ }^{* * *} p<0.001$ ). (For interpretation of the references to color in this figure legend the reader is referred to the web version of this article.)

\subsection{Hoechst 33342 and propidium iodide labeling}

In monolayer cultures, the culture medium was removed following treatment, and cells were fixed with paraformaldehyde (4\%; $15 \mathrm{~min})$. Cells were stained with Hoechst $33342(10 \mu \mathrm{M}$; $10 \mathrm{~min}$ ), and then washed and kept in PBS. Cell imaging was conducted using an automated microscopy platform (Operetta High Content Imaging System; Perkin Elmer, United States). Image analysis and cell counting were performed using the Columbus Image Data Storage and Analysis platform (Perkin Elmer, United States). In spheroid cultures, propidium iodide and Hoechst 33342 fluorescent dyes were added $3 \mathrm{~h}$ prior to measurements. At the end of treatment, individual spheroids were carefully transferred onto a microscope slide using a pipette, and flattened under a glass coverslip to facilitate imaging. Imaging was conducted using a fluorescence microscope, and fluorescence intensity was quantified using ImageJ.

\subsection{Biosensor construction}

The caspase- 3 biosensor consists of two parts (Fig. 3). Plasmid 1 encodes the green dimerization-dependent fluorescent protein
(GA) linked with a nuclear exclusion signal sequence (NES; LALKLAGLDIGS) $[48,49]$, the caspase-3 substrate sequence (DEVD) [50], and a partner protein (B) linked to a nuclear localization signal (NLS; DPKKKRKVDPKKKRKVDPKKKRKV) [51]. Plasmid 2 encodes the dimerization-dependent red fluorescent protein (RA) linked with a NLS. Expression and purification of constructs 1 and 2 were performed according to procedures previously described in detail [38]. Details of the plasmid constructs are found in Table 1.

\subsection{Plasmid preparation and transfection}

Stocks of the caspase-3 biosensor plasmids (kindly provided by Dr. Robert E. Campbell, University of Alberta, Canada) were prepared in $\alpha$-Select Escherichia coli (Bioline, United States) using a Miniprep Kit (Qiagen, Canada). DNA concentration was adjusted to $1 \mu \mathrm{g} / \mu \mathrm{l}$ in purified water, and plasmids were stored at $-20^{\circ} \mathrm{C}$. For transfection, U251N cells were seeded in black 96-well plates (Corning, United States) at a density of 10,000 cells per well, and cultured for $24 \mathrm{~h}$. Transfection was conducted in the absence of antibiotics, using Lipofectamine 2000 (Invitrogen, Canada), following the procedure recommended by the manufacturer. The transfection complexes were kept for $24 \mathrm{~h}$, after which the medium was replaced by complete medium, and cells were treated.

\subsection{Live cell imaging of the caspase-3 biosensor}

Monolayer cells seeded in black 96-well cell culture plates were transfected with the biosensor, and treated for $24 \mathrm{~h}$. Following treatment, cells were imaged using the Operetta High Content Imaging System to analyze green (eGFP) and red (Alexa 594) signals. Caspase- 3 activity was quantified as the number of cells with red nuclei, and expressed as a percentage of total transfected cells (expressing green or red fluorescence). The absence of caspase-3 activity was quantified from the number of cells with green cytoplasm, and expressed in the same manner. Eleven fields were analyzed per well, with six wells per treatment group. Negative controls were non-transfected cells in the presence or absence of drugs. Following treatment, transfected spheroids were transferred onto microscope slides, flattened under glass coverslips, and imaged using a fluorescence microscope. Full spheroids were imaged and the number of cells with green fluorescence in the cytoplasm or red fluorescence in the nucleus was counted.

\subsection{Statistical analysis}

Each experiment was independently performed at least two or three times. Each treatment was performed in three samples (24well plates) or six samples (96-well plates). All data are expressed as mean \pm SEM values. Statistical significance was calculated using one-way ANOVA, followed by the Student's t-test. For multiple comparisons, Bonferroni corrections were applied.

\section{Results}

\subsection{Curcumin is sequestered in lipid droplets}

Due to its fluorescent properties, curcumin's intracellular localization can be visualized using a fluorescence microscope $(488 / 509 \mathrm{~nm})$. After treating U251N glioblastoma cells with curcumin $(10 \mu \mathrm{m})$ for $4 \mathrm{~h}$, green fluorescence was found diffused throughout the cells, located at cell membranes, and concentrated in numerous punctate in the cytoplasm (Fig. 1A). Staining of curcumin-treated cells with Nile Red, a lipophilic stain for intracellular lipids, showed that curcumin co-localized with membrane 

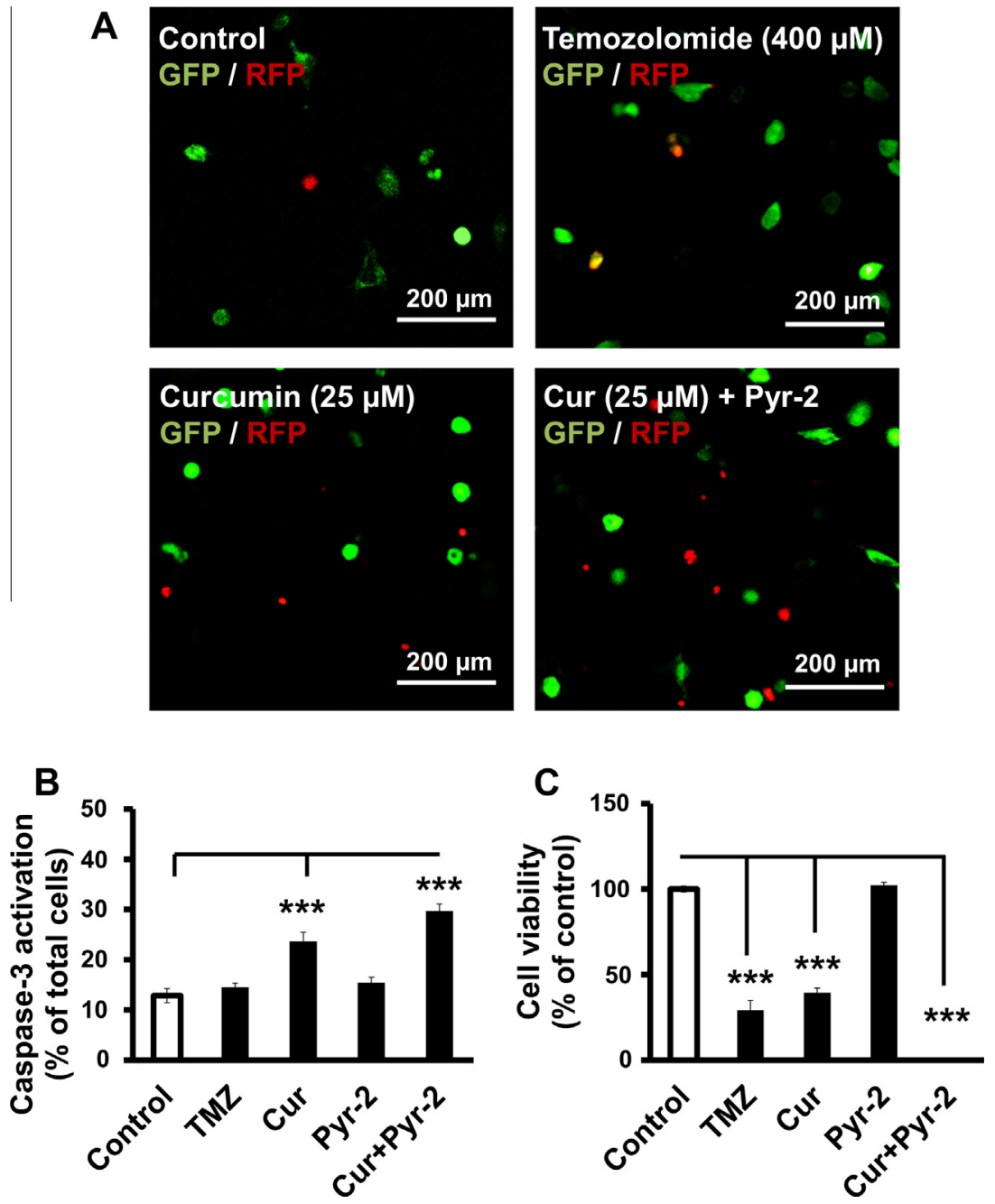

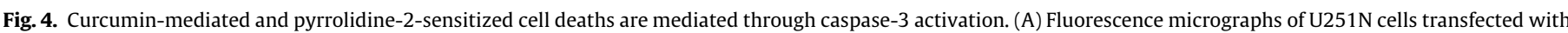

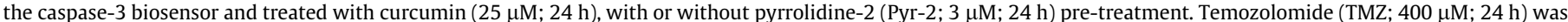

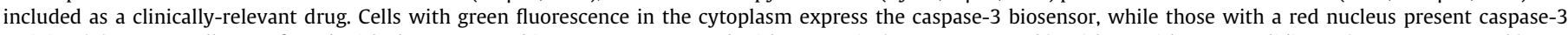

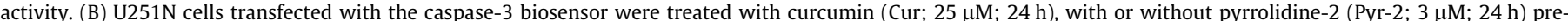

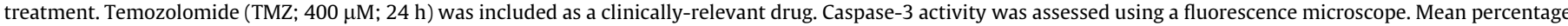

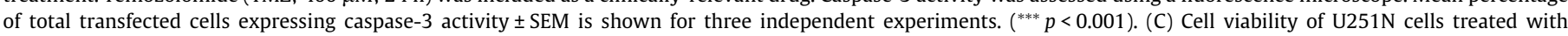

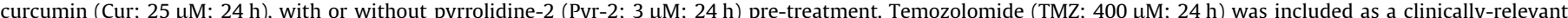

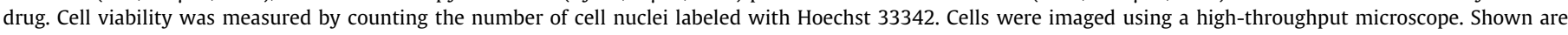
average percentage values \pm SEM compared to untreated controls from three independent experiments. $\left({ }^{* * *} p<0.001\right)$.

lipids and lipid droplets. Given the importance of lipid droplets for cancer cells, we then employed pyrrolidine-2, an inhibitor of cPLA2 $\alpha$, to reduce lipid droplet number in glioblastoma cells. U251N cells normally contain lipid droplets and their number can be reduced using inhibitors of lipid droplet formation, or increased using fatty acids such as oleic acid (Fig. S1). Pyrrolidine-2 treatment ( $3 \mu \mathrm{M} ; 24 \mathrm{~h}$ ) reduced lipid droplet number to $52 \pm 5.7 \%$ of untreated control levels (Fig. 1C). Lipid droplet number in cells treated with both curcumin and pyrrolidine-2 was higher $(82.3 \pm 16.0 \%)$ than that of cells treated with pyrrolidine- 2 alone.

\subsection{Pyrrolidine-2 potentiates the cell killing effect of curcumin}

We postulated that U251N glioblastoma cells would be more susceptible to the therapeutic effects of curcumin following the reduction of lipid droplet number by pyrrolidine-2. Cell viability measured by counting cell nuclei labeled with Hoechst 33342 showed that $25 \mu \mathrm{M}$ of curcumin decreased cell number to $53.8 \pm 2.8 \%$ after $24 \mathrm{~h}$ of treatment (Fig. $2 \mathrm{~A}$ and $\mathrm{B}$ ). In turn, pyrrolidine-2 alone did not induce any significant decrease in cell viability up to $4 \mu \mathrm{M}$ (Fig. 2C). Pre-treatment of U251N cells with pyrrolidine-2 potentiated the cell killing effect of curcumin. Notably, pre-treatment with pyrrolidine-2 $(24 \mathrm{~h})$ virtually abolished glioblastoma viability when followed by curcumin treatment (72 h) at concentrations above $20 \mu \mathrm{M}$ (Fig. 2B). In comparison, pyrrolidine-2 modestly increased the effectiveness of temozolomide, which was included as a clinically relevant comparator (Fig. S2). The effect of pyrrolidine-2 as a sensitizer was compared to that of BSO. Although pre-treatment with BSO increased cell death at lower concentrations of curcumin, it did not substantially increase cell death at higher concentrations (Fig. S3).

3.3. Cell death induced by curcumin and pyrrolidine-2 is mediated by caspase-3

To investigate the mode of cell death induced by curcumin and pyrrolidine-2, we employed a newly developed biosensor for caspase- 3 activation. This construct offers a highly sensitive method to detect caspase-3-mediated apoptosis in live cells. In 
A
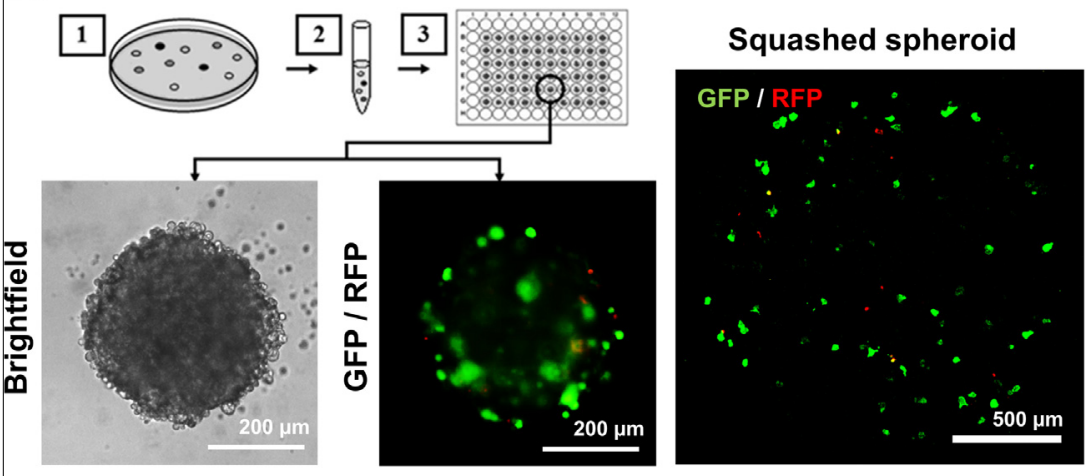

B

$24 h$

C $\quad 72 \mathrm{~h}$
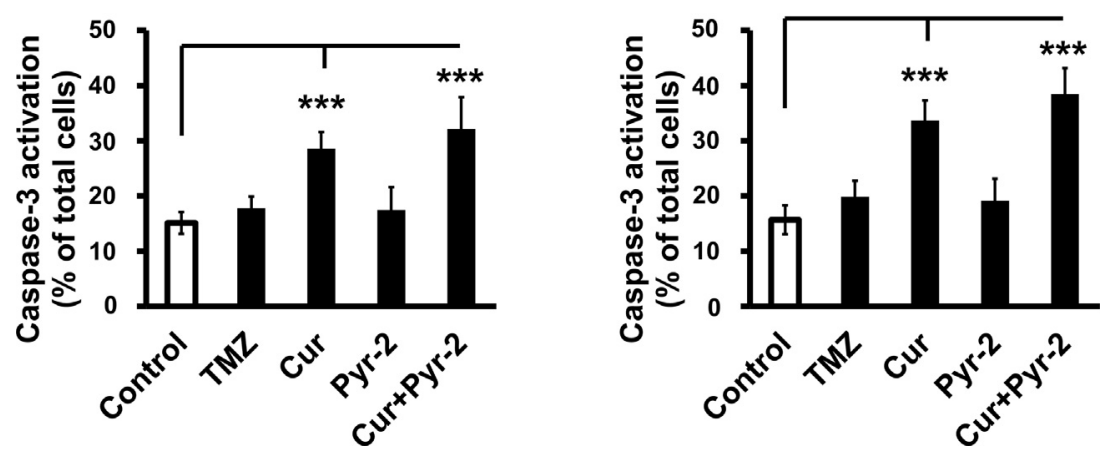

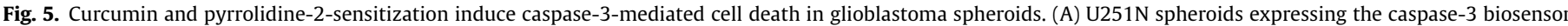

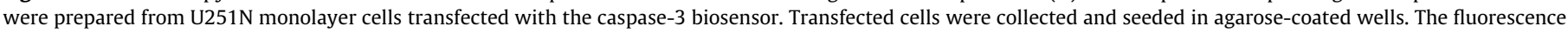

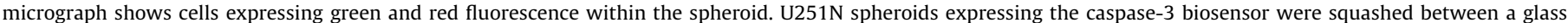

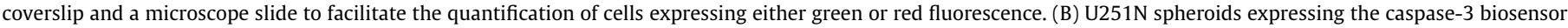

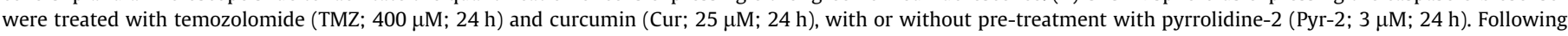

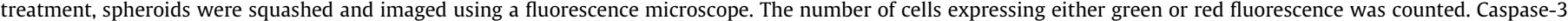

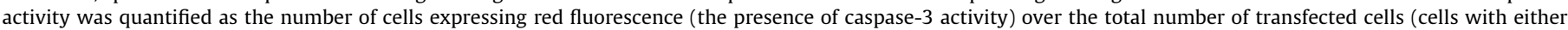

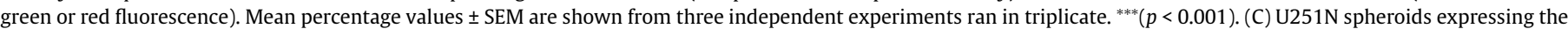

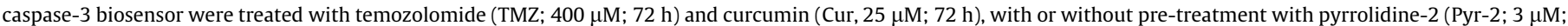

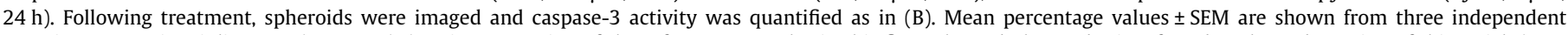
experiments ran in triplicate. ${ }^{* * *}(p<0.001)$. (For interpretation of the references to color in this figure legend, the reader is referred to the web version of this article.)

the absence of caspase- 3 activity, cells expressing the biosensor display green fluorescence in the cytoplasm. Following the activation of caspase-3, green fluorescence fades and red fluorescence increases in the cell nucleus. Thus, caspase- 3 activity can be quantified by counting the number of cells with red fluorescence as a proportion of total transfected cells expressing either green or red fluorescence. Experiments showed that even under control conditions, a small proportion of cells (13.2 $\pm 1.4 \%)$ display caspase- 3 activity. In turn, the positive control staurosporine, a potent activator of caspase-3, significantly increased the proportion of cells with a red nucleus (Fig. 3D).

To compare the mode of cell death induced by curcumin and pyrrolidine-2-sensitized curcumin treatments, U251N cells transfected with the caspase- 3 biosensor were treated with monoand combination therapies for $24 \mathrm{~h}$. The results showed that although temozolomide, curcumin and pyrrolidine-2-sensitized treatments all significantly reduced cell viability in U251N cells, only curcumin (alone or in combination) significantly induced caspase-3-mediated cell death (Fig. 4B and C).

\subsection{Curcumin and pyrrolidine-2 are effective in glioblastoma spheroids}

To further investigate the effectiveness of curcumin and pyrrolidine-2, we used glioblastoma spheroids cultures, which more closely represent brain tumors found in vivo. Following the preparation of U251N spheroids using cells transfected with the caspase-3 biosensor, spheroids were treated at drug concentrations found to be effective in monolayer experiments. Due to their 3D structure, spheroids were "squashed" between two glass surfaces in order to disperse the cells and facilitate their imaging (Fig. 5A). Both curcumin and curcumin combined with pyrrolidine-2 induced a time-dependent increase in caspase-3 activity. In contrast, cytotoxic concentrations of temozolomide did not induce caspase-3 activity, even after $72 \mathrm{~h}$ (Fig. 5B and C).

To relate caspase- 3 activity to overall cell viability, we used Hoechst 33342 and propidium iodide labeling to examine the importance of necrotic cell death (Fig. 6). The results showed that a time-dependent increase in necrotic cell death was seen in response to temozolomide, curcumin and curcumin combined with pyrrolodine-2. Yet, the most dramatic increase was seen with the combination treatment, where the rate of necrotic cell death almost doubled from $24 \mathrm{~h}$ to $72 \mathrm{~h}$ of treatment (Fig. 6B and C).

\section{Discussion}

In the nervous system, the presence of lipid droplets in neurons is minimal, and is most noticeable in glia cells under physiological conditions. In many models of neurodegeneration, the excessive accumulation of lipid droplets in glial cells is a hallmark of disease and is linked to mitochondrial dysfunction [19]. In glioblastoma multiforme, the accumulation of lipid droplets serves to fuel tumor 

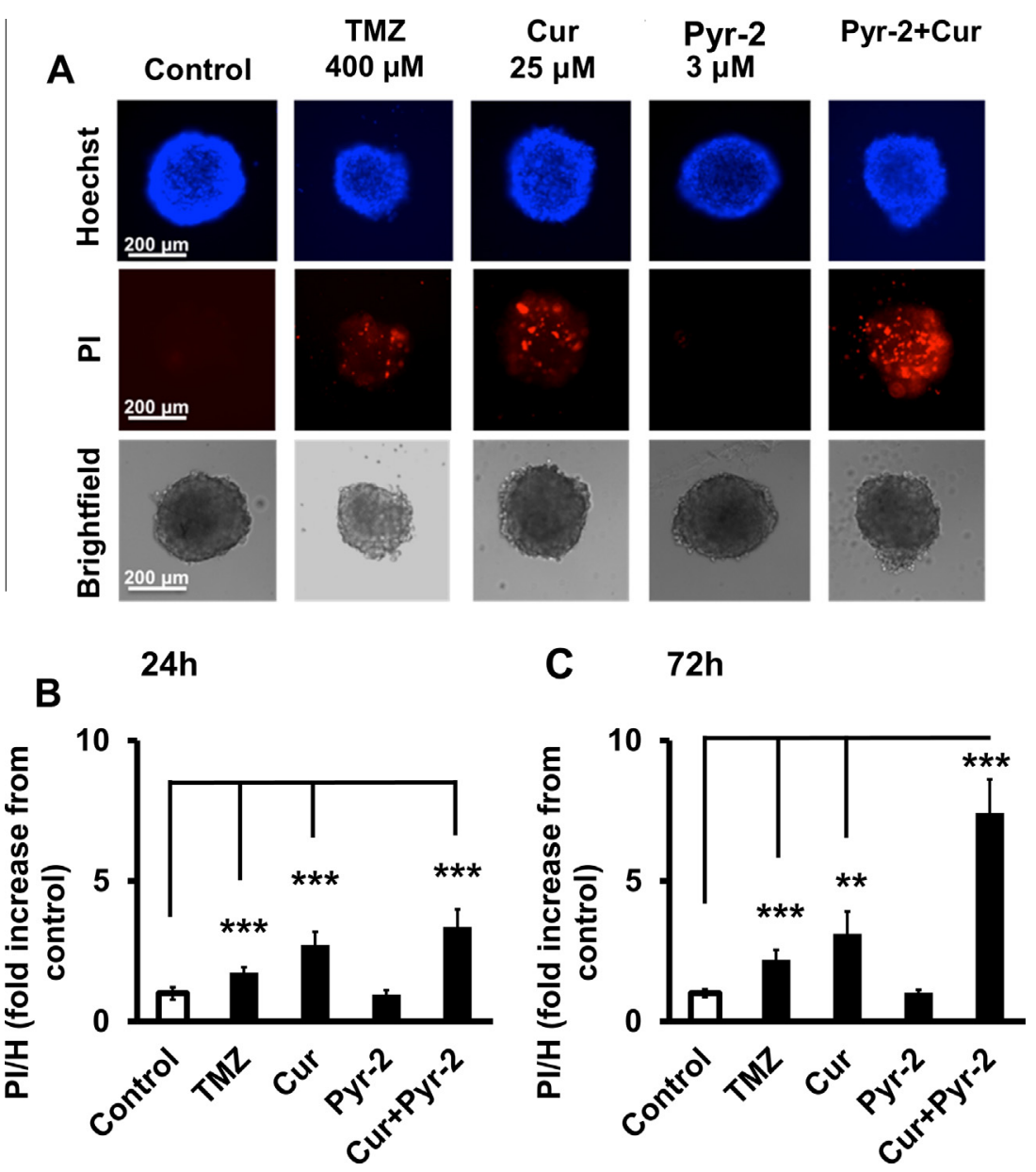

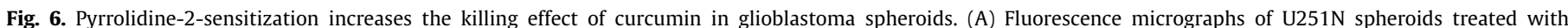

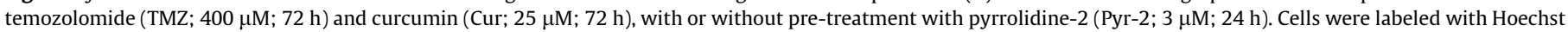

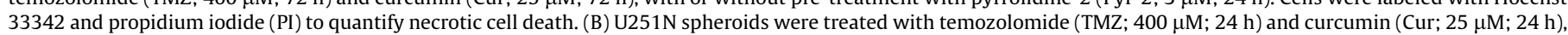

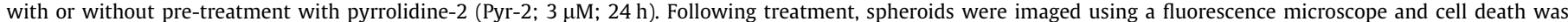

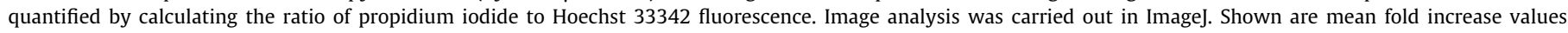

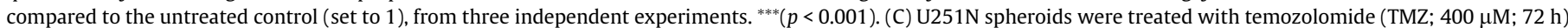

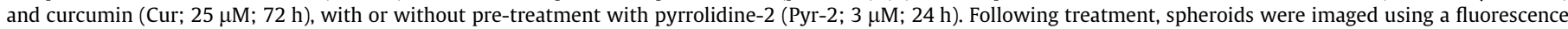

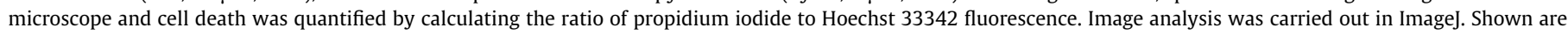
mean fold increase values compared to the untreated control (set to 1$)$, from three independent experiments. ${ }^{* *}(p<0.01)$, ${ }^{* * *}(p<0.001)$.

growth and resist therapeutic treatments. Aside from providing energy to resist stress induced by chemotherapeutic drugs, it appears that lipid droplets can also directly decrease the amount of drugs available at targets by sequestering them inside the core of the lipid droplets. We hypothesized that the pharmacological inhibition of lipid droplet formation and the reduction of lipid droplet number in glioblastoma cells are viable strategies to increase the effectiveness of lipophilic chemotherapeutic drugs such as curcumin. The mechanisms involved are summarized in Fig. 7. Curcumin is a hydrophobic compound owing to its aromatic phenolic groups and methylene bridge [52,53]. The high lipophilicity of curcumin is indicated by its octanol-water partition coefficient of $2.5 \times 10^{4} \mathrm{M}^{-1}[54,55]$. Curcumin's partition coefficient for 1,2-dioleoyl-sn-glycero-3-phosphocholine (DOPC) lipid bilayers and HEPES buffer was $2.4 \times 10^{4} \mathrm{M}^{-1}$ [56]. This high partition coefficient clearly indicates curcumin's preference for lipophilic cellular compartments. As such, it can rapidly cross cell membranes and localize in lipid droplets (Fig. 1A). In contrast, analysis using Time-of-Flight Secondary Ion Mass Spectrometry (TOF-SIMS) showed that temozolomide did not localize in lipid droplets (data not shown). The inhibition of lipid droplet formation can thus serve two purposes: (1) to lower the capacity of glioblastoma cells to withstand curcumin-induced stress by reducing their energy stores, and (2) to reduce the amount of compartments where curcumin can be sequestered, thereby increasing drug availability at targets. Different kinds of delivery systems have been used to deliver curcumin to the brain and to glioblastoma in vivo [57-59]. Polymeric carriers have the potential to improve the stability and solubility of curcumin [60-62]. Our research group has previously reported the incorporation of curcumin into A2B star polymer micelles and effectiveness of this preparation in glioblastoma $[63,64]$. A retention of curcumin's biological activity in nanocarriers, an enhanced permeability and retention (EPR) effect and diffusion of curcumin into the neighboring glioblastoma cells could provide an improved therapeutic intervention in vivo [65]

Pyrrolidine- 2 is an inhibitor of cPLA2 $\alpha$, a key rate limiting enzyme in the synthesis of eicosanoids and a necessary player in the formation of lipid droplets [66,67]. In normal brain tissues, particularly in astrocytes and microglia, excessive PLA2 activation in response to stressors (e.g. glutamate excitotoxicity) can exacerbate inflammatory processes and oxidative stress. In turn, these can promote neurological disorders such as Alzheimer's disease, Parkinson's disease, and traumatic brain injuries [68]. In glioblastoma cells, cPLA2 $\alpha$ activity is likely to be upregulated in response 


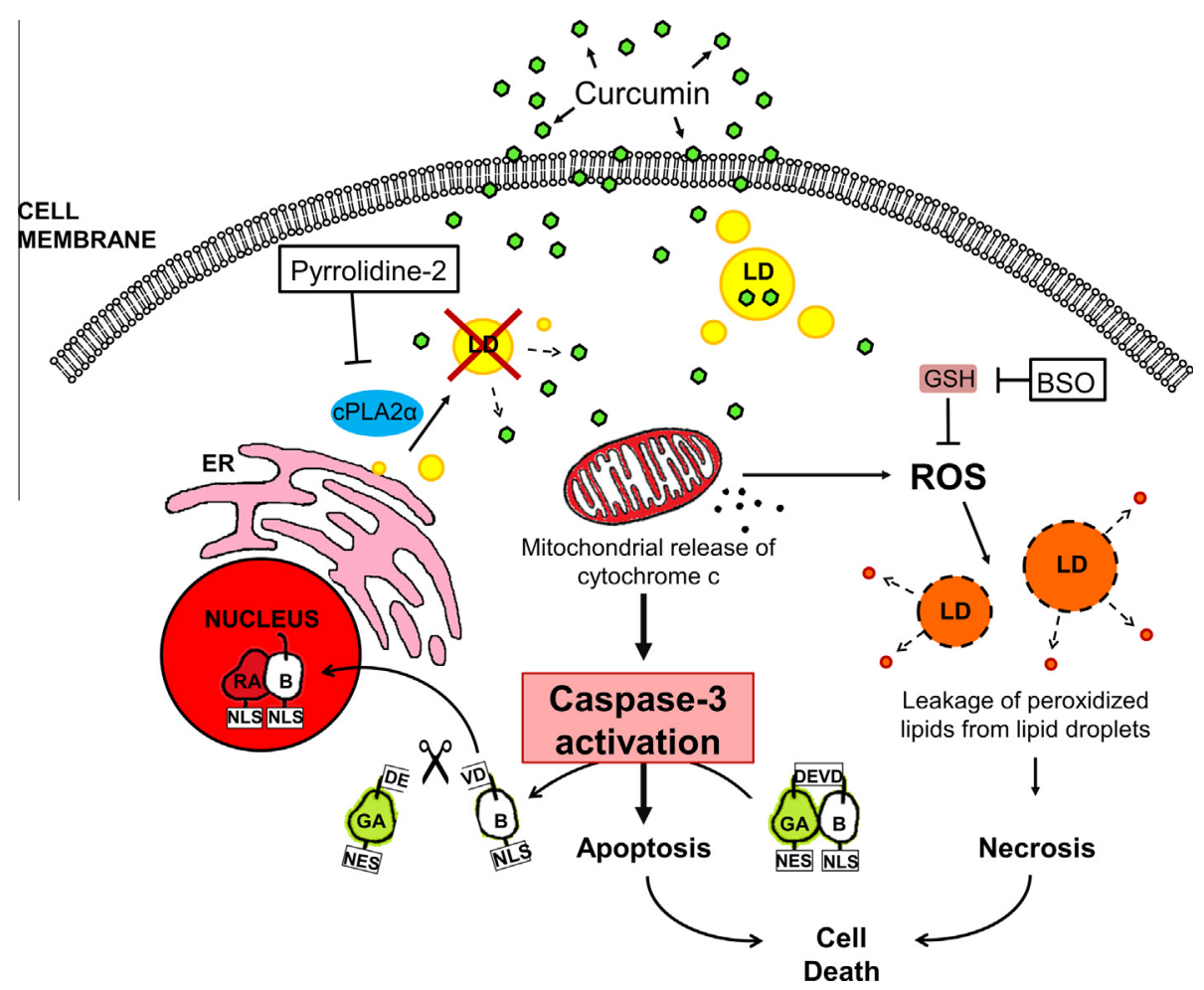

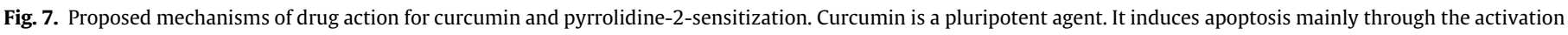

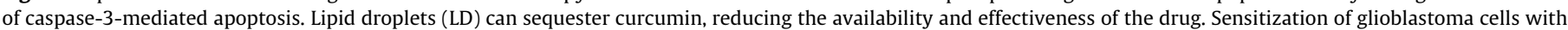

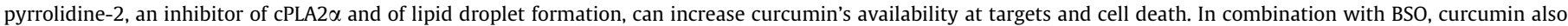

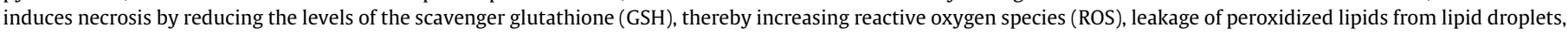
and cell death.

to chemotherapeutic intervention, allowing cancer cells to stock up in energy and adapt their metabolic pathways. Although pyrrolidine-2 treatment alone does not induce significant loss in cell viability in U251N glioblastoma cells up to $4 \mu \mathrm{M}$, its effect becomes apparent when followed by curcumin treatments. Our results show that pyrrolidine-2 pre-treatment dramatically increased the effectiveness of curcumin in U251N cells after $72 \mathrm{~h}$, virtually abolishing cell viability at curcumin concentrations above $20 \mu \mathrm{M}$. Interestingly, the lipid droplet number of cells treated with curcumin following pyrrolidine-2 sensitization was higher than that of cells treated with curcumin alone - likely due to the drug-induced cellular stress, previously reported to induce lipid droplet formation $[19,69,70]$. Sensitization using BSO was comparatively less effective, likely due to the diversity of antioxidants and enzymes that can reduce ROS levels. Nevertheless, the depletion of glutathione by BSO increased curcumin-mediated cell death, possibly through the increased peroxidation of lipid droplets, and necrosis (Fig. 7)[71].

To investigate the mode of cell death induced by curcumin and pyrrolidine-2, we employed a highly sensitive biosensor to detect and measure caspase- 3 activity in live cells [38]. The mechanism of the biosensor relies on a bi-modular design, in which two fluorescent proteins with dimerization-dependent brightness are activated in a mutually-exclusive manner. When challenged with proapoptotic stimuli, cells transfected with the biosensor manifest a change in fluorescence color, from green to red, and in signal localization, from the cytosol to the nucleus. In the absence of caspase-3 activity, the green cytoplasmic protein is linked with a nonfluorescent partner protein which increases green fluorescence manyfolds. Following the activation of caspase-3 during apoptosis, the caspase- 3 substrate (DEVD) contained in the linker region is cleaved, and green fluorescence is dramatically decreased. The partner protein then translocates into the nucleus and associates with high affinity to the red fluorescent protein, enhancing red fluorescence manyfold. Thus, the specificity of detection is based on (1) the caspase-3 substrate, (2) the change in the color of the signal, and (3) the change in the subcellular localization of the signal. It is to note that a small proportion of cells display caspase- 3 activity under control conditions. Our results support previous findings stating that curcumin is a strong inducer of caspase-3-mediated apoptosis in cancer cells $[41,42]$. In contrast, temozolomideinduced cell death did not implicate caspase- 3 activation, suggesting the involvement of other modes of cell death, such as autophagy [72]. Autophagy is usually reduced in cells with a large number of lipid droplets, which could partly explain the limited effectiveness of temozolomide against glioblastoma tumors $[73,74]$.

In normal brain tissues, it appears that CPLA2 $\alpha$ and lipid droplets play protective roles, notably helping glia cells to support neurons and resist stressors. For example, cPLA2 $\alpha(+/+)$ mice were found to be more resistant to hypoxic conditions resulting from brain ischemia than their null counterparts [75]. Excessive CPLA2 $\alpha$ activity has also been involved in apoptosis, as it was found to drive arachidonic acid-mediated cytotoxicity and subsequent caspase-3 activation [76]. On the other hand, the protective role of lipid droplets in glioblastoma cells is highly detrimental to cancer patients. The inhibition of CPLA $2 \alpha$ is one of several approaches recently investigated to hinder lipid metabolism in cancer cells. Small molecules and gene silencing (e.g. acetyl-CoA carboxylase alpha) were shown to be effective in inhibiting cancer cell proliferation and viability in vitro [77-79]. However, most experiments performed in monolayer cancer cell cultures do not accurately reflect the conditions found in in vivo, where the intercellular contact, tumor dynamics and overall heterogeneous microenvironment 
found in tumors often heighten resistance to radiotherapy and chemotherapy [80-82]. Glioblastoma spheroids harbor hypoxic cores where metabolic pathways, including those involving lipids, are changed [4,83-85]. De novo lipogenesis, for instance, was shown to be bypassed in cancer cells in hypoxic conditions. Instead, cancer cells relied on extracellular lipid scavenging to supply for their needs [6]. Thus, we conducted experiments in 3D spheroid, and confirmed that pyrrolidine-2 pre-treatment enhanced the cell killing effect of curcumin in a time- and caspase-3-dependent manner. In contrast, temozolomide alone was significantly less effective at inducing caspase-3 activation and glioblastoma cell death.

Because of the importance of CPLA2 $\alpha$ in lipid metabolism and the production of pro-inflammatory mediators, its inhibition has also been studied in the context of inflammatory conditions such as arthritis [86,87]. The microenvironment of glioblastoma tumors is characterized by the infiltration of hyperactivated immune cells, which aggravate disease progression. Thus, it can be hypothesized that inhibition of lipid metabolism can also reduce inflammation at tumor sites [88-90]. However, the potential side effects of pyrrolidine-2 deter its use in vivo. One of the best tolerated statins is simvastatin [91]. Statins were tested in some CNS diseases and were suggested as supplemental anticancer agents [92,93]. Thus, the administration of simvastatin in combination with curcumin might be a suitable therapeutic strategy for certain groups of glioblastoma patients.

Taken together, our results indicate that lipid droplets in glioblastoma cells play a protective role by sequestering drugs and promoting cell survival. Decreased lipid droplet formation using pyrrolidine- 2 as a sensitizing agent significantly increases the cell killing effect of chemotherapeutic agents such as curcumin.

\section{Acknowledgments}

The present study was supported by CIHR (MOP-119425) and NSERC (RGPIN-2015-04994) grants. The authors have no conflicts of interest to declare.

\section{Appendix A. Supplementary material}

Supplementary data associated with this article can be found, in the online version, at http://dx.doi.org/10.1016/j.ejpb.2015.12.008.

\section{References}

[1] K. Gupta, I. Kalra, P. Salunke, R.K. Vasishta, Lipidized glioblastoma: a rare differentiation pattern, Neuropathology 31 (2011) 93-97.

[2] L.K. Boroughs, R.J. DeBerardinis, Metabolic pathways promoting cancer cell survival and growth, Nat. Cell Biol. 17 (2015) 351-359.

[3] J.A. Menendez, R. Lupu, Fatty acid synthase and the lipogenic phenotype in cancer pathogenesis, Nat. Rev. Cancer 7 (2007) 763-777.

[4] F. Baenke, B. Peck, H. Miess, A. Schulze, Hooked on fat: the role of lipid synthesis in cancer metabolism and tumour development, Dis. Models Mech. 6 (2013) 1353-1363.

[5] F.P. Kuhajda, Fatty acid synthase and cancer: new application of an old pathway, Cancer Res. 66 (2006) 5977-5980.

[6] J.J. Kamphorst, J.R. Cross, J. Fan, E. de Stanchina, R. Mathew, E.P. White, C.B. Thompson, J.D. Rabinowitz, Hypoxic and Ras-transformed cells support growth by scavenging unsaturated fatty acids from lysophospholipids, Proc. Natl. Acad. Sci. USA 110 (2013) 8882-8887.

[7] F.P. Kuhajda, K. Jenner, F.D. Wood, R.A. Hennigar, L.B. Jacobs, J.D. Dick, G.R. Pasternack, Fatty acid synthesis: a potential selective target for antineoplastic therapy, Proc. Natl. Acad. Sci. USA 91 (1994) 6379-6383.

[8] A.D. Patterson, O. Maurhofer, D. Beyoglu, C. Lanz, K.W. Krausz, T. Pabst, F.J. Gonzalez, J.F. Dufour, J.R. Idle, Aberrant lipid metabolism in hepatocellular carcinoma revealed by plasma metabolomics and lipid profiling, Cancer Res. 71 (2011) 6590-6600.

[9] P. Prasanna, A. Thibault, L. Liu, D. Samid, Lipid metabolism as a target for brain cancer therapy: synergistic activity of lovastatin and sodium phenylacetate against human glioma cells, J. Neurochem. 66 (1996) 710-716.

[10] A.G. Renehan, M. Zwahlen, M. Egger, Adiposity and cancer risk: new mechanistic insights from epidemiology, Nat. Rev. Cancer 15 (2015) 484-498.
[11] Nor E. Sounni, J. Cimino, S. Blacher, I. Primac, A. Truong, G. Mazzucchelli, A. Paye, D. Calligaris, D. Debois, P. De Tullio, B. Mari, E. De Pauw, A. Noel, Blocking lipid synthesis overcomes tumor regrowth and metastasis after antiangiogenic therapy withdrawal, Cell Metab. 20 (2014) 280-294.

[12] A. Umemura, Eek J. Park, K. Taniguchi, Jun H. Lee, S. Shalapour, Mark A. Valasek, M. Aghajan, H. Nakagawa, E. Seki, Michael N. Hall, M. Karin, Liver damage, inflammation, and enhanced tumorigenesis after persistent mTORC1 inhibition, Cell Metab. 20 (2014) 133-144.

[13] C.R. Santos, A. Schulze, Lipid metabolism in cancer, FEBS J. 279 (2012) 2610 2623.

[14] J.V. Swinnen, K. Brusselmans, G. Verhoeven, Increased lipogenesis in cancer cells: new players, novel targets, Curr. Opin. Clin. Nutr. Metab. Care 9 (2006) 358-365.

[15] A.D. Barbosa, D.B. Savage, S. Siniossoglou, Lipid droplet-organelle interactions: emerging roles in lipid metabolism, Curr. Opin. Cell Biol. 35 (2015) 91-97.

[16] H.F. Hashemi, J.M. Goodman, The life cycle of lipid droplets, Curr. Opin. Cell Biol. 33 (2015) 119-124.

[17] D.A. Gross, D.L. Silver, Cytosolic lipid droplets: from mechanisms of fat storage to disease, Crit. Rev. Biochem. Mol. Biol. 49 (2014) 304-326.

[18] M.T. Accioly, P. Pacheco, C.M. Maya-Monteiro, N. Carrossini, B.K. Robbs, S.S Oliveira, C. Kaufmann, J.A. Morgado-Diaz, P.T. Bozza, J.P. Viola, Lipid bodies are reservoirs of cyclooxygenase-2 and sites of prostaglandin-E2 synthesis in colon cancer cells, Cancer Res. 68 (2008) 1732-1740.

[19] M.A. Welte, Expanding roles for lipid droplets, Curr. Biol. 25 (2015) R470R481.

[20] A.R. Thiam, R.V. Farese Jr., T.C. Walther, The biophysics and cell biology of lipid droplets, Nat. Rev. Mol. Cell Biol. 14 (2013) 775-786.

[21] S. Rak, T. De Zan, J. Stefulj, M. Kosovic, O. Gamulin, M. Osmak, FTIR spectroscopy reveals lipid droplets in drug resistant laryngeal carcinoma cells through detection of increased ester vibrational bands intensity, Analyst 139 (2014) 3407-3415.

[22] D. Lagoutte, V. Nicolas, E. Poupon, A. Fournet, R. Hocquemiller, D. Libong, P. Chaminade, P.M. Loiseau, Antifungal canthin-6-one series accumulate in lipid droplets and affect fatty acid metabolism in Saccharomyces cerevisiae, Biomed. Pharmacother. 62 (2008) 99-103.

[23] S.C. Gupta, S. Patchva, B.B. Aggarwal, Therapeutic roles of curcumin: lessons learned from clinical trials, AAPS J. 15 (2013) 195-218.

[24] J.K. Lin, Molecular targets of curcumin, Adv. Exp. Med. Biol. 595 (2007) $227-$ 243.

[25] A.L. Cheng, C.H. Hsu, J.K. Lin, M.M. Hsu, Y.F. Ho, T.S. Shen, J.Y. Ko, J.T. Lin, B.R. Lin, W. Ming-Shiang, H.S. Yu, S.H. Jee, G.S. Chen, T.M. Chen, C.A. Chen, M.K. Lai, Y.S. Pu, M.H. Pan, Y.J. Wang, C.C. Tsai, C.Y. Hsieh, Phase I clinical trial of curcumin, a chemopreventive agent, in patients with high-risk or premalignant lesions, Anticancer Res. 21 (2001) 2895-2900.

[26] N. Dhillon, B.B. Aggarwal, R.A. Newman, R.A. Wolff, A.B. Kunnumakkara, J.L. Abbruzzese, C.S. Ng, V. Badmaev, R. Kurzrock, Phase II trial of curcumin in patients with advanced pancreatic cancer, Clin. Cancer Res. 14 (2008) 4491 4499.

[27] P. Anand, A.B. Kunnumakkara, R.A. Newman, B.B. Aggarwal, Bioavailability of curcumin: problems and promises, Mol. Pharm. 4 (2007) 807-818.

[28] T. Ono, K. Yamada, Y. Chikazawa, M. Ueno, S. Nakamoto, T. Okuno, K. Seno, Characterization of a novel inhibitor of cytosolic phospholipase A2alpha, pyrrophenone, Biochem. J. 363 (2002) 727-735.

[29] A. Gubern, J. Casas, M. Barcelo-Torns, D. Barneda, X. de la Rosa, R. Masgrau, F. Picatoste, J. Balsinde, M.A. Balboa, E. Claro, Group IVA phospholipase A2 is necessary for the biogenesis of lipid droplets, J. Biol. Chem. 283 (2008) 2736927382.

[30] A.L. Cohen, H. Colman, Glioma biology and molecular markers, Cancer Treat. Res. 163 (2015) 15-30.

[31] V.A. Cuddapah, S. Robel, S. Watkins, H. Sontheimer, A neurocentric perspective on glioma invasion, Nat. Rev. Neurosci. 15 (2014) 455-465.

[32] R. Stupp, W.P. Mason, M.J. van den Bent, M. Weller, B. Fisher, M.J. Taphoorn, K. Belanger, A.A. Brandes, C. Marosi, U. Bogdahn, J. Curschmann, R.C. Janzer, S.K. Ludwin, T. Gorlia, A. Allgeier, D. Lacombe, J.G. Cairncross, E. Eisenhauer, R.O. Mirimanoff, Radiotherapy plus concomitant and adjuvant temozolomide for glioblastoma, N. Engl. J. Med. 352 (2005) 987-996.

[33] K. Petrecca, M.C. Guiot, V. Panet-Raymond, L. Souhami, Failure pattern following complete resection plus radiotherapy and temozolomide is at the resection margin in patients with glioblastoma, J. Neurooncol. 111 (2013) 1923.

[34] M. Weller, T. Cloughesy, J.R. Perry, W. Wick, Standards of care for treatment of recurrent glioblastoma-are we there yet? Neuro-Oncology 15 (2013) 4-27

[35] M.E. Hegi, A.C. Diserens, T. Gorlia, M.F. Hamou, N. de Tribolet, M. Weller, J.M. Kros, J.A. Hainfellner, W. Mason, L. Mariani, J.E. Bromberg, P. Hau, R.O. Mirimanoff, J.G. Cairncross, R.C. Janzer, R. Stupp, MGMT gene silencing and benefit from temozolomide in glioblastoma, The New England journal of medicine 352 (2005) 997-1003.

[36] O.W. Griffith, Mechanism of action, metabolism, and toxicity of buthionine sulfoximine and its higher homologs, potent inhibitors of glutathione synthesis, J. Biol. Chem. 257 (1982) 13704-13712.

[37] C.P. Anderson, C.P. Reynolds, Synergistic cytotoxicity of buthionine sulfoximine (BSO) and intensive melphalan (L-PAM) for neuroblastoma cell lines established at relapse after myeloablative therapy, Bone Marrow Transplant. 30 (2002) 135-140.

[38] Y. Ding, J. Li, J.R. Enterina, Y. Shen, I. Zhang, P.H. Tewson, G.C. Mo, J. Zhang, A.M. Quinn, T.E. Hughes, D. Maysinger, S.C. Alford, Y. Zhang, R.E. Campbell, 
Ratiometric biosensors based on dimerization-dependent fluorescent protein exchange, Nat. Methods 12 (2015) 195-198.

[39] G. Kroemer, L. Galluzzi, P. Vandenabeele, J. Abrams, E.S. Alnemri, E.H. Baehrecke, M.V. Blagosklonny, W.S. El-Deiry, P. Golstein, D.R. Green, M. Hengartner, R.A. Knight, S. Kumar, S.A. Lipton, W. Malorni, G. Nuñez, M.E. Peter, J. Tschopp, J. Yuan, M. Piacentini, B. Zhivotovsky, G. Melino, Classification of cell death: recommendations of the Nomenclature Committee on Cell Death 2009, Cell Death Differ. 16 (2009) 3-11.

[40] J.M. Brown, L.D. Attardi, The role of apoptosis in cancer development and treatment response, Nat. Rev. Cancer 5 (2005) 231-237.

[41] R.J. Anto, A. Mukhopadhyay, K. Denning, B.B. Aggarwal, Curcumin (diferuloylmethane) induces apoptosis through activation of caspase-8, BID cleavage and cytochrome c release: its suppression by ectopic expression of Bcl-2 and Bcl-xl, Carcinogenesis 23 (2002) 143-150.

[42] E. Sikora, A. Bielak-Zmijewska, A. Magalska, K. Piwocka, G. Mosieniak, M Kalinowska, P. Widlak, I.A. Cymerman, J.M. Bujnicki, Curcumin induces caspase-3-dependent apoptotic pathway but inhibits DNA fragmentation factor 40/caspase-activated DNase endonuclease in human Jurkat cells, Mol. Cancer Ther. 5 (2006) 927-934.

[43] R. Gogada, M. Amadori, H. Zhang, A. Jones, A. Verone, J. Pitarresi, S. Jandhyam, V. Prabhu, J.D. Black, D. Chandra, Curcumin induces Apaf-1-dependent, p21 mediated caspase activation and apoptosis, Cell Cycle (Georgetown, Tex.) 10 (2011) 4128-4137.

[44] R.S. Dhanikula, A. Argaw, J.F. Bouchard, P. Hildgen, Methotrexate loaded polyether-copolyester dendrimers for the treatment of gliomas: enhanced efficacy and intratumoral transport capability, Mol. Pharm. 5 (2008) 105-116.

[45] R.C. Melo, H. D’Avila, P.T. Bozza, P.F. Weller, Imaging lipid bodies within leukocytes with different light microscopy techniques, Methods Mol. Biol. (Clifton, N.J.) 689 (2011) 149-161.

[46] P. Greenspan, E.P. Mayer, S.D. Fowler, Nile red: a selective fluorescent stain for intracellular lipid droplets, J. Cell Biol. 100 (1985) 965-973.

[47] D.L. Sackett, J. Wolff, Nile red as a polarity-sensitive fluorescent probe of hydrophobic protein surfaces, Anal. Biochem. 167 (1987) 228-234.

[48] W. Wen, J.L. Meinkoth, R.Y. Tsien, S.S. Taylor, Identification of a signal for rapid export of proteins from the nucleus, Cell 82 (1995) 463-473.

[49] S.C. Alford, A.S. Abdelfattah, Y. Ding, R.E. Campbell, A fluorogenic red fluorescent protein heterodimer, Chem. Biol. 19 (2012) 353-360.

[50] X. Xu, A.L. Gerard, B.C. Huang, D.C. Anderson, D.G. Payan, Y. Luo, Detection of programmed cell death using fluorescence energy transfer, Nucleic Acids Res. 26 (1998) 2034-2035.

[51] R.B. Moreland, H.G. Nam, L.M. Hereford, H.M. Fried, Identification of a nuclear localization signal of a yeast ribosomal protein, Proc. Natl. Acad. Sci. USA 82 (1985) 6561-6565.

[52] K.I. Priyadarsini, Chemical and structural features influencing the biological activity of curcumin, Curr. Pharm. Des. 19 (2013) 2093-2100.

[53] B.B. Aggarwal, B. Sung, Pharmacological basis for the role of curcumin in chronic diseases: an age-old spice with modern targets, Trends Pharmacol. Sci. 30 (2009) 85-94.

[54] M. Heger, R.F. van Golen, M. Broekgaarden, M.C. Michel, The molecular basis for the pharmacokinetics and pharmacodynamics of curcumin and its metabolites in relation to cancer, Pharmacol. Rev. 66 (2014) 222-307.

[55] A. Kunwar, A. Barik, R. Pandey, K.I. Priyadarsini, Transport of liposomal and albumin loaded curcumin to living cells: an absorption and fluorescence spectroscopic study, Biochim. Biophys. Acta 1760 (2006) 1513-1520.

[56] W.C. Hung, F.Y. Chen, C.C. Lee, Y. Sun, M.T. Lee, H.W. Huang, Membranethinning effect of curcumin, Biophys. J . 94 (2008) 4331-4338.

[57] R.L. Shinde, G.P. Bharkad, P.V. Devarajan, Intranasal microemulsion for targeted nose to brain delivery in neurocysticercosis: role of docosahexaenoic acid, Eur. J. Pharm. Biopharm. Off. J. Arbeitsgemeinschaft fur Pharmazeutische Verfahrenstechnik e.V 96 (2015) 363-379.

[58] S. Wang P. Chen, L. Zhang C. Yang G. Zhai, Formulation and evaluation of microemulsion-based in situ ion-sensitive gelling systems for intranasal administration of curcumin, J. Drug Target. 20 (2012) 831-840.

[59] X. Chen, F. Zhi, X. Jia, X. Zhang, R. Ambardekar, Z. Meng, A.R. Paradkar, Y. Hu, Y. Yang, Enhanced brain targeting of curcumin by intranasal administration of a thermosensitive poloxamer hydrogel, J. Pharm. Pharmacol. 65 (2013) 807-816.

[60] O. Naksuriya, Y. Shi, C.F. van Nostrum, S. Anuchapreeda, W.E. Hennink, S. Okonogi, HPMA-based polymeric micelles for curcumin solubilization and inhibition of cancer cell growth, Eur. J. Pharm. Biopharm. Off. J. Arbeitsgemeinschaft fur Pharmazeutische Verfahrenstechnik e.V 94 (2015) $501-512$.

[61] J.M. Rabanel, J. Faivre, G.D. Paka, C. Ramassamy, P. Hildgen, X. Banquy, Effect of polymer architecture on curcumin encapsulation and release from PEGylated polymer nanoparticles: toward a drug delivery nano-platform to the CNS, Eur. J. Pharm. Biopharm. Off. J. Arbeitsgemeinschaft fur Pharmazeutische Verfahrenstechnik e.V 96 (2015) 409-420.

[62] X. Yang, Z. Li, N. Wang, L. Li, L. Song, T. He, L. Sun, Z. Wang, Q. Wu, N. Luo, C. Yi, C. Gong, Curcumin-encapsulated polymeric micelles suppress the development of colon cancer in vitro and in vivo, Sci. Rep. 5 (2015) 10322

[63] G.M. Soliman, S. Anjali, C. Yiming, S. Rishi, K. Ashok, M. Dusica, Miktoarm sta micelles containing curcumin reduce cell viability of sensitized glioblastoma, J. Nanomedine Biotherapeutic Discov. 4 (2014) e1000124.

[64] A. Moquin, A. Sharma, Y. Cui, A. Lau, D. Maysinger, A. Kakkar, Asymmetric AB miktoarm star polymers: synthesis, self-assembly, and study of micelle stability using AF for efficient drug delivery, Macromol. Biosci. (2015).
[65] F. Schütze, F. Röhrig, S. Vorlová, S. Gätzner, A. Kuhn, S. Ergün, E. Henke, Inhibition of lysyl oxidases improves drug diffusion and increases efficacy of cytotoxic treatment in 3D tumor models, Sci. Rep. 5 (2015) 17576.

[66] D.T. Stephenson, J.V. Manetta, D.L. White, X.G. Chiou, L. Cox, B. Gitter, P.C. May, J.D. Sharp, R.M. Kramer, J.A. Clemens, Calcium-sensitive cytosolic phospholipase A2 (cPLA2) is expressed in human brain astrocytes, Brain Res. 637 (1994) 97-105.

[67] K. Seno, T. Okuno, K. Nishi, Y. Murakami, F. Watanabe, T. Matsuura, M. Wada, Y. Fujii, M. Yamada, T. Ogawa, T. Okada, H. Hashizume, M. Kii, S. Hara, S. Hagishita, S. Nakamoto, K. Yamada, Y. Chikazawa, M. Ueno, I. Teshirogi, T. Ono, M. Ohtani, Pyrrolidine inhibitors of human cytosolic phospholipase A(2), J. Med. Chem. 43 (2000) 1041-1044.

[68] G.Y. Sun, P.B. Shelat, M.B. Jensen, Y. He, A.Y. Sun, A. Simonyi, Phospholipases A2 and inflammatory responses in the central nervous system, NeuroMol. Med. 12 (2010) 133-148.

[69] A.G. Cabodevilla, L. Sánchez-Caballero, E. Nintou, V.G. Boiadjieva, F. Picatoste, A. Gubern, E. Claro, Cell survival during complete nutrient deprivation depends on lipid droplet-fueled $\beta$-oxidation of fatty acids, J. Biol. Chem. 288 (2013) 27777-27788.

[70] A. Khatchadourian, S.D. Bourque, V.R. Richard, V.I. Titorenko, D. Maysinger, Dynamics and regulation of lipid droplet formation in lipopolysaccharide (LPS)-stimulated microglia, Biochim. Biophys. Acta 2012 (1821) 607-617.

[71] L. Liu, K. Zhang, H. Sandoval, S. Yamamoto, M. Jaiswal, E. Sanz, Z. Li, J. Hui, B.H. Graham, A. Quintana, H.J. Bellen, Glial lipid droplets and ROS induced by mitochondrial defects promote neurodegeneration, Cell 160 (2015) 177-190.

[72] T. Kanzawa, IM. Germano, T. Komata, H. Ito, Y. Kondo, S. Kondo, Role of autophagy in temozolomide-induced cytotoxicity for malignant glioma cells, Cell Death Differ. 11 (2004) 448-457.

[73] J. Sesen, P. Dahan, S.J. Scotland, E. Saland, V.T. Dang, A. Lemarie, B.M. Tyler, H. Brem, C. Toulas, E. Cohen-Jonathan Moyal, JE. Sarry, N. Skuli, Metformin inhibits growth of human glioblastoma cells and enhances therapeutic response, PLoS One 10 (2015) e0123721.

[74] Z. Zhang, J. Wang, Y. Shen, C. Guo, K. Sai, F. Chen, X. Mei, F. Han, Z. Chen, Dihydroartemisinin increases temozolomide efficacy in glioma cells by inducing autophagy, Oncol. Lett. 10 (2015) 379-383.

[75] S. Tabuchi, N. Uozumi, S. Ishii, Y. Shimizu, T. Watanabe, T. Shimizu, Mice deficient in cytosolic phospholipase A2 are less susceptible to cerebral ischemia/reperfusion injury, Acta Neurochir. Suppl. 86 (2003) 169-172.

[76] M. Nakanishi, D.W. Rosenberg, Roles of cPLA(2) $\alpha$ and arachidonic acid in cancer, Biochim. Biophys. Acta 1761 (2006) 1335-1343.

[77] M. Hilvo, C. Denkert, L. Lehtinen, B. Muller, S. Brockmoller, T. Seppanen-Laakso, J. Budczies, E. Bucher, L. Yetukuri, S. Castillo, E. Berg, H. Nygren, M. Sysi-Aho, J. L. Griffin, O. Fiehn, S. Loibl, C. Richter-Ehrenstein, C. Radke, T. Hyotylainen, O. Kallioniemi, K. Iljin, M. Oresic, Novel theranostic opportunities offered by characterization of altered membrane lipid metabolism in breast cancer progression, Cancer Res. 71 (2011) 3236-3245.

[78] X. Cai, X. Hu, X. Tan, W. Cheng, Q. Wang, X. Chen, Y. Guan, C. Chen, X. Jing, Metformin induced AMPK activation, G0/G1 phase cell cycle arrest and the inhibition of growth of esophageal squamous cell carcinomas in vitro and in vivo, PLoS One 10 (2015) e0133349.

[79] F.P. Kuhajda, E.S. Pizer, J.N. Li, N.S. Mani, G.L. Frehywot, C.A. Townsend, Synthesis and antitumor activity of an inhibitor of fatty acid synthase, Proc. Natl. Acad. Sci. USA 97 (2000) 3450-3454.

[80] W. He, Y. Kuang, X. Xing, R.J. Simpson, H. Huang, T. Yang, J. Chen, L. Yang, E. Liu, W. He, J. Gu, Proteomic comparison of 3D and 2D glioma models reveals increased HLA-E expression in 3D models is associated with resistance to NK cell-mediated cytotoxicity, J. Proteome Res. 13 (2014) 2272-2281.

[81] D. Zips, H.D. Thames, M. Baumann, New anticancer agents: in vitro and in vivo evaluation, Vivo 19 (2005) $1-7$

[82] M. Hakanson, M. Textor, M. Charnley, Engineered 3D environments to elucidate the effect of environmental parameters on drug response in cancer, Integr. Biol. (Camb.) 3 (2011) 31-38.

[83] P. Kucharzewska, H.C. Christianson, M. Belting, Global profiling of metabolic adaptation to hypoxic stress in human glioblastoma cells, PLoS One 10 (2015) e0116740.

[84] P. Chinnaiyan, E. Kensicki, G. Bloom, A. Prabhu, B. Sarcar, S. Kahali, S. Eschrich, X. Qu, P. Forsyth, R. Gillies, The metabolomic signature of malignant glioma reflects accelerated anabolic metabolism, Cancer Res. 72 (2012) 5878-5888.

[85] D. Ackerman, M.C. Simon, Hypoxia, lipids, and cancer: surviving the harsh tumor microenvironment, Trends Cell Biol. 24 (2014) 472-478.

[86] M.A. Balboa, R. Perez, J. Balsinde, Amplification mechanisms of inflammation: paracrine stimulation of arachidonic acid mobilization by secreted phospholipase A2 is regulated by cytosolic phospholipase A2-derived hydroperoxyeicosatetraenoic acid, J. Immunol. (Baltimore, Md.: 1950) 171 (2003) (1950) 989-994.

[87] N. Tai, K. Kuwabara, M. Kobayashi, K. Yamada, T. Ono, K. Seno, Y. Gahara, J. Ishizaki, Y. Hori, Cytosolic phospholipase A2 alpha inhibitor, pyrroxyphene, displays anti-arthritic and anti-bone destructive action in a murine arthritis model, Inflammat. Res. Off. J. Euro. Histamine Res. Soc. . . [et al.] 59 (2010) 5362.

[88] G. Desmarais, G. Charest, D. Fortin, R. Bujold, D. Mathieu, B. Paquette, Cyclooxygenase-2 inhibitor prevents radiation-enhanced infiltration of F98 glioma cells in brain of Fischer rat, Int. J. Radiat. Biol. (2015) 1-10.

[89] J.L. Sowers, K.M. Johnson, C. Conrad, J.T. Patterson, L.C. Sowers, The role of inflammation in brain cancer, Adv. Exp. Med. Biol. 816 (2014) 75-105. 
[90] M. Tafani, M. Di Vito, A. Frati, L. Pellegrini, E. De Santis, G. Sette, A. Eramo, P. Sale, E. Mari, A. Santoro, A. Raco, M. Salvati, R. De Maria, M.A. Russo, Proinflammatory gene expression in solid glioblastoma microenvironment and in hypoxic stem cells from human glioblastoma, J. Neuroinflammation 8 (2011) 32.

[91] H. Naci, J. Brugts, T. Ades, Comparative tolerability and harms of individual statins: a study-level network meta-analysis of 246955 participants from 135

randomized, controlled trials, Circ. Cardiovasc. Qual. Outcomes 6 (2013) 390 399.

[92] D. Gaist, J. Hallas, S. Friis, S. Hansen, H.T. Sorensen, Statin use and survival following glioblastoma multiforme, Cancer Epidemiol. 38 (2014) 722-727.

[93] T. Menge, H.P. Hartung, O. Stuve, Statins - a cure-all for the brain?, Nat Rev Neurosci. 6 (2005) 325-331. 